Çukurova Üniversitesi Mühendislik Mimarlık Fakültesi Dergisi, 33(3), ss. 41-56, Eylül 2018

Çukurova University Journal of the Faculty of Engineering and Architecture, 33(3), pp. 41-56, September 2018

\title{
Tutak (Ăgrı) Volkanitlerinin Jeokimyası ve Petrolojisi: Amfibolce Zengin Granat Peridotitin Kısmi Ergimesi
}

\author{
Vural OYAN"1 \\ ${ }^{1}$ Van Yüzüncü Yıl Üniversitesi, Mühendislik Fakültesi, Maden Mühendisliği Bölümü, Van
}

Geliş tarihi: 13.07.2018～Kabul tarihi: 15.10 .2018

\section{$\ddot{O} \mathbf{z}$}

Türkiye'nin kuzeydoğusunda yer alan Pliyosen yaşlı Tutak volkanitleri, Doğu Anadolu Bölgesi'nde çarpışmayla ilişkili en önemli bazaltik platolardan biridir. Volkanik ürünler bazaltik bileşime sahiptirler ve alkali-subalkali ayrım çizgisi üzerine iz düşerler. Bazaltik kayaçların tamamı olivin, piroksen, plajiyoklaz ve opak mineral fenokristalleri ve mikrolitlerinden oluşur ve intersertal, subofitik ve akma dokuları sergilerler. Fraksiyonel kristallenme ve EC-AFC (enerjiye bağımlı fraksiyonel kristallenme, ile birleşik asimilasyon) modelleri Tutak volkanitlerinin evriminde fraksiyonel kristallenme ve kitasal kirlenmenin önemli rol oynadıklarına işaret eder. En az evrimleşmiş (yüksek $\mathrm{MgO}$ içerikli lavlar) bazaltik örneklerinin düşük ${ }^{143} \mathrm{Nd} /{ }^{144} \mathrm{Nd}$ ve yüksek ${ }^{87} \mathrm{Sr} /{ }^{86} \mathrm{Sr}$ izotopik oranları ile büyük iyon yarıçaplı litofil (BIYÇL) ve hafif nadir toprak elementlerinin (HNTE), yüksek alan şiddetli elementlerine (YAŞE) göre belirgin zenginleşmesi, manto kaynak alanında yitim bileşeninin varlığına ve baskın olarak sediment ergimeleri ile zenginleştĭgine işaret eder. Nadir torak element sistematiğinin kullanılması ile üretilen kısmi ergime modelleri, bazaltik ergiyiklerin kısmi ergime derecesi $\% 0,7$ ile $\% 2$ arasında değişen ve amfibol ile granat içeren metasomatize olmuş manto kaynağının ergimesi ile üretilebileceğini göstermiştir.

Anahtar Kelimeler: Doğu Anadolu, Volkanizma, AFC, Kısmi ergime, Amfibol

\section{Geochemistry and Petrology of Tutak (Ăgrı) Volcanic Rocks: Partial Melting of Amphibole Bearing Garnet Peridotite}

\begin{abstract}
The Pliocene aged Tutak volcanic rocks located in the northeast of Turkey is one of the most important basaltic plateaus related to the collision in the East Anatolia. Volcanic products have basaltic compositions and they plot on alkaline-sub-alkaline division line. All of the basaltic lavas composed of olivine, pyroxene, plagioclase and opaque mineral phenocrystals and microlites, displaying intersertal, subophitic and flow textures. Fractional crystallisation and EC-RAFC (Energy-constrained assimilation, fractional crystallisation and magma recharge) models indicate that fractional crystallisation and crustal
\end{abstract}

*Sorumlu yazar (Corresponding author): Vural OYAN, vuraloyan@yyu.edu.tr 
contamination play an important role in the evolution of the Tutak volcanic rocks. Lower ${ }^{144} \mathrm{Nd} /{ }^{143} \mathrm{Nd}$ and higher ${ }^{87} \mathrm{Sr} /{ }^{86} \mathrm{Sr}$ isotopic ratios and enrichment of large ion lithophile elements (LILE) and light rare earth elements (LREE) relative to high strength field elements (HFSE) of the least evolved basaltic samples indicate that the mantle source region might be enriched by melts that were derived from subducted sediments. Partial melting models generated by using rare earth element systematics calculations show that basaltic melts might have been produced by melting of a metasomatised mantle source containing both amphibole and garnet with a partial melting degree between 0.2 and $2 \%$.

Keywords: East Anatolia, Volcanism, AFC, Partial melting, Amphibole

\section{GİRIŞ}

Türkiye - İran Platosu (Şekil 1) üzerindeki geç Senozoyik volkanizma Batı Anadolu'dan başlayarak Orta Anadolu ve Doğu Anadolu'ya, oradan da komşu ülkelerden Gürcistan, Ermenistan, İran, Azerbeycan ve Rusya'ya kadar uzanan geniş bir yayılım göstermektedir [1-8]. Türkiye-İran platosunun batı-kuzeybatısında yer alan Doğu Anadolu Bölgesi, Neotetis Okyanusu'nun kuzeye doğru dalıp batması sonucunda tüketilmesini izleyen evrede Avrasya ve Arabistan levhaları arasındaki çarpışma ile ilişkili ve deniz seviyesinden yaklaşık $2 \mathrm{~km}$ yükseklikte, yüksek bir plato olarak meydana gelmiştir. Bölgesel boyutta kubbe (regional dome) şekilli bir yapıya sahip olan $[9,10]$ Doğu Anadolu Bölgesinde bahsi geçen çarpışmanın sonucu olarak doğu-batı uzanımlı kıvrımlar, ters faylar ve doğrultu atımlı iki grup fay sistemi gelişmiştir [11]. Son yapılan çalışmalar Doğu Anadolu bölgesindeki son okyanusal litosferin $20 \mathrm{My}$ önce tamamen tükendiğine işaret etmektedir [12]. Arabistan ve Avrasya plakları arasındaki çarpışmanın yaşı halen tartışmalı olsa da, bölgedeki granitlerden elde edilen yaş verileri çarpışmanın en erken Erken Miyosen veya Geç Oligosen'de meydana gelmiş olması gerektiğini ortaya koymaktadır. [13,14]. Bölgedeki volkanik aktivite iki kıtasal levhanın çarpışması sonucunda bölgede meydana gelen blok yükselimini takiben yaklaşık 15 My önce andezitik volkanizma ile başlamış [15] ve bölgede yaygınca yüzeyleyen lav akışları ve piroklastik ürünler üretmiştir. Bunlar üç farklı tip (efüzif, ekstrüsif, eksplosif) patlama dinamiğinin ürünleri olarak ortaya çıkmıştır. $\mathrm{Bu}$ jeodinamiksel evrim içerisinde, Doğu Anadolu bölgesi yaklaşık 2/3'ü Miyosen'den günümüze değișen yaşlar sunan genç volkanik kayaçlarla kaplı olup kıta-kıta çarpışma kuşakları için dünyadaki en iyi örneklerden birini teşkil etmektedir. Geç Miyosen sonu ve Erken Pliyosen'e kadar sıkışma büzülme rejimi ile karakterize olan Doğu Anadolu'daki tektonik rejim, Erken-Geç Pliyosen'de yerini sıkışmaaçılma tektonik rejimine bırakmıştır [16].

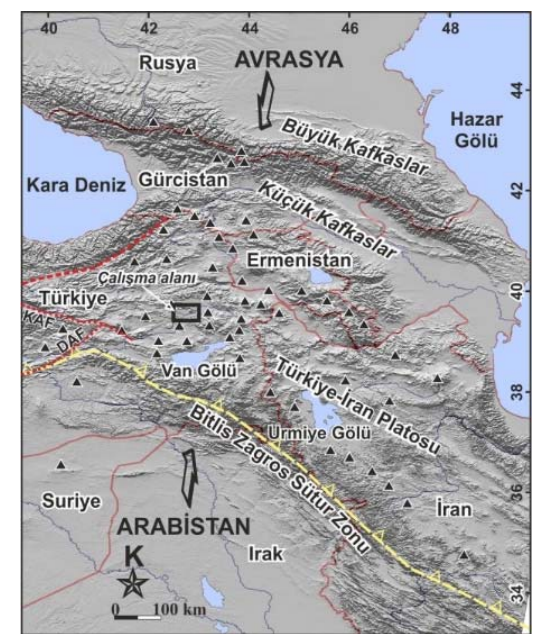

Şekil 1. Türkiye-İran yüksek platosunun ve çalışma alanının kabartı rölyef haritası üzerindeki konumları (Oyan ve arkadaşları [21]'den değiştirilerek alınmıştır). İçi dolu üçgenler bölgedeki volkanik merkezleri göstermektedir

$\mathrm{Bu}$ neotektonik yapı içerisinde çarpışma sonrası volkanizma Miyosen'den Kuvaterner'e kadar Ağrı, Tendürek, Etrüsk, Aladağ, Süphan ve Nemrut gibi büyük volkanik sistemler veya açılma çatlakları boyunca püskürmüştür. Doğu Anadolu bölgesi için birçok araştırmacı farklı jeodinamik modeller önermişlerdir $\quad[1-3,7,9,17-20]$. $\mathrm{Bu}$ jeodinamik 
modeller içinde; (i) litosferik mantonun kısmi olarak koparak ayrılması [1], (ii) dalan okyanusal litosferin dikleşmesi ve kırılmasını (slab steeping and break off) takiben litosferik mantonun yerine yitim bileşeni ile zenginleşmiş astenoferik mantonun yükselmesi $(3,9,10,19]$ en çok kabul görenleridir.

Bölgedeki magmatik aktivitenin petrolojisi ve kaynak alanına ilişkin son çalışmalar [7,20,21], bu iki farklı modele paralel olarak yitim bileşeni içeren veya içermeyen litosferik ve astenosferik mantoların farklı oranlarda ve farklı ergime derecelerinde karışımı ile bölge çapında yoğun magmatik etkinliği üretilebileceğini ileri sürmüştür.

Doğu Anadolu Bölgesi'nde magmatizma üzerine gerçekleştirilen çalışmalar, çoğunlukla büyük volkanik merkezlerin veya geniş platolar oluşturan bazaltik volkanizma alanlarının petrolojik olarak çözümlenmesini kapsamaktadır. Bu çalışma ile Doğu Anadolu Yüksek Platosu üzerinde gelişmiş olan ve mafik volkanizma ürünü lavlar püskürten Tutak volkanitleri ilk kez detaylı veri seti üretilmiş ve değerlendirilmiştir. Bu çalışma ile; (i) volkanizmayı oluşturan magma odası veya odalarının evrimleşme süreçleri iz element ve izotopik veriler kullanılarak ortaya koyulmuş ve petrolojik modellemeler ile desteklenmiștir. (ii) Elde edilen veriler ile manto kaynak alanının zenginleşme süreçleri ve kaynak alan mineralojisinin ne olabileceği kısmi ergime modelleri ve iz element ve izotopik oranlar kullanılarak belirlenmiş ve hem yerel olarak Tutak volkanizmasının hemde Doğu Anadolu bölgesindeki volkanizmanın jeodinamik süreçleri ile manto kaynak alanlarının ne olabileceği tartışılmıştır.

\section{MATERYAL VE METOT}

Arazi çalışmaları ile volkanizmayı en iyi karakterize eden kayaçlardan örnekler toplanmış, analitik veri setini üretmek için gerekli olan taze ve temiz örnekler olmasına özen gösterilmiştir. Derlenen örnekler petrografik, jeokimyasal ve izotopik analizler için hazırlanmıştır. Örnekler Struers marka elmas kesme diski kullanılarak kesilmiștir. Petrografik analizler için alınmış olan örnekler uygun boyutta kesilerek plakalar halinde hazırlanmış, 30 mikron boyutlarında mineralojikpetrografik analizler için incekesitler haline getirilmiş, tanımlamalar için polarizan mikroskoplarda incelenmiştir.

Seçilen temsilci örnekler jeokimya ve izotop analizleri için hazırlanmıştır. Elmas kesme diskiyle örneklerin dış kısmındaki toz, toprak, yosun ve ikincil oluşumlar kesilerek temizlenmiştir. Daha sonra çeneli kırıcı kullanılarak kırılan numuneler agat havan yardımıyla öğütülmüş ve analizler için hazırlanmıştır.

Ana, iz ve nadir toprak element analizleri (Çizelge 1) Kanada'daki Acme Analitik Laboratuvarlarında (Acme labs) yaptırılmıştır. Ana element oksit analizleri lityum mataborat/tetraborat füzyon tekniği kullanılarak ICP-ES (indüklenerek eşleşmiş plazma emisyon spektrometresi) cihazı ile ölçülerek elde edilmiştir. Ana element oksitleri için dedeksiyon limitleri \%0,001 ile 0,04 arasında değişmektedir. Ateşte kayıp (LOI), örneğin ayrıştırılmasında $900{ }^{\circ} \mathrm{C}$ 'de ve 2 saat ateşleme yöntemi ile belirlenmiş ve sonra ağırlık kaybının ölçülmesi ile elde edilmiştir. İz ve nadir toprak element analizleri için, 0,2 g örnek grafit krozelerde $\quad \mathrm{LiBO}_{2} / \mathrm{Li}_{2} \mathrm{~B}_{4} \mathrm{O}_{7}$ ile karıştırılmıştır. Hazırlanan krozeler fırında kaynatılmıştır. Daha sonra erimiş örnekler $\% 5 \mathrm{HNO}_{3}$ 'de çözdürülmüş ve ICP-MS (indüklenerek eşleşmiş plazma kütle spektrometresi) cihazında ölçülmüştür. Sr-Nd izotopik analizleri Orta Doğu Teknik Üniversitesi Merkez Laboratuvarı bünyesindeki radyojenik izotop laboratuvarlarında yaptırılmıştır. Köksal ve Göncüoğlu'nda [22] detayları ve koşulları verilen metodlardan uyarlanmış olan TLM-ARG-RİL-01 (Sr İzotop Oranı Analizi Deney Talimatı) ve TLMARG-RILL-02 (Nd İzotop Oranı Analizi Deney Talimatı) talimatları uygulanarak yapılmıştır. Tartım, kimyasal çözme ve kromatografi işlemleri 100 temizlik standardında temiz laboratuvar koşullarında gerçekleştirilmiştir. Herbir kayaç pudrası örneğinden yaklaşık $80 \mathrm{mg}$ tartılarak PFA şişelere aktarılmıştır. Numuneler, $4 \mathrm{~mL} \% 52 \mathrm{HF}$ içinde 4 gün süreyle $160{ }^{\circ} \mathrm{C}$ 'lik 1 sitıcı tabla üzerinde bekletilerek tamamen çözülmüştür. Isıtıcı tabla üzerinde kurutulan örnekler önce $4 \mathrm{~mL} 6$ 
$\mathrm{NHCl}$ içinde bir gün süreyle çözülmüştür. Numuneler daha sonra tekrar isitıcı table üzerinde buharlaştırılıp kurutularak $1 \mathrm{~mL} \mathrm{2,5} \mathrm{N} \mathrm{HCl}$ içine alınmış ve kromatografiye hazır duruma getirilmiştir.

${ }^{87} \mathrm{Sr} /{ }^{86} \mathrm{Sr}$ verileri ${ }^{86} \mathrm{Sr} /{ }^{88} \mathrm{Sr}=0,1194$ 'e oranlanmış ve ölçümler sırasında Sr NBS 987 standardı $0,710261 \pm 10 \quad(\mathrm{n}=4)$ olarak ölçülmüş ve ölçüm sonuçları üzerinde gerekli bias düzeltmesi yapılmıştır. Neodmiyum izotop analizler sırasında, ${ }^{143} \mathrm{Nd} /{ }^{144} \mathrm{Nd}$ verileri ${ }^{146} \mathrm{Nd} /{ }^{144} \mathrm{Nd}=0,7219$ ile oranlanmış, Nd LaJolla standardı ise $0,511847 \pm 5$ $(n=4)$ olarak ölçülmüştür. Nd izotop oranı ölçüm sonuçları üzerinde herhangi bir bias düzeltmesi yapılmamıştır. Ölçümler, Triton Termal
İyonizasyon Kütle Spektrometresi (ThermoFisher) kullanılarak çoklu-toplama ile yapılmıştır. Analitik belirsizlikler 2 sigma düzeyindedir.

\section{2. ÇALIŞMA ALANININ JEOLOJİSI}

Tutak volkanitleri Doğu Anadolu Bölgesi'nin kuzeyinde Tutak ili ve çevrelerinde geniş alanlarda gözlenen, hem geniş plato lavları oluşturmuş hemde yerel volkanik merkezlerden püskürmüş lav serileri ile karakteristiktir (Şekil 2). Önceki çalışmalardan elde edilmiş yaş verileri [23] bu volkanizmanın Pliyosen döneminde püskürdüğüne işaret etmektedir.

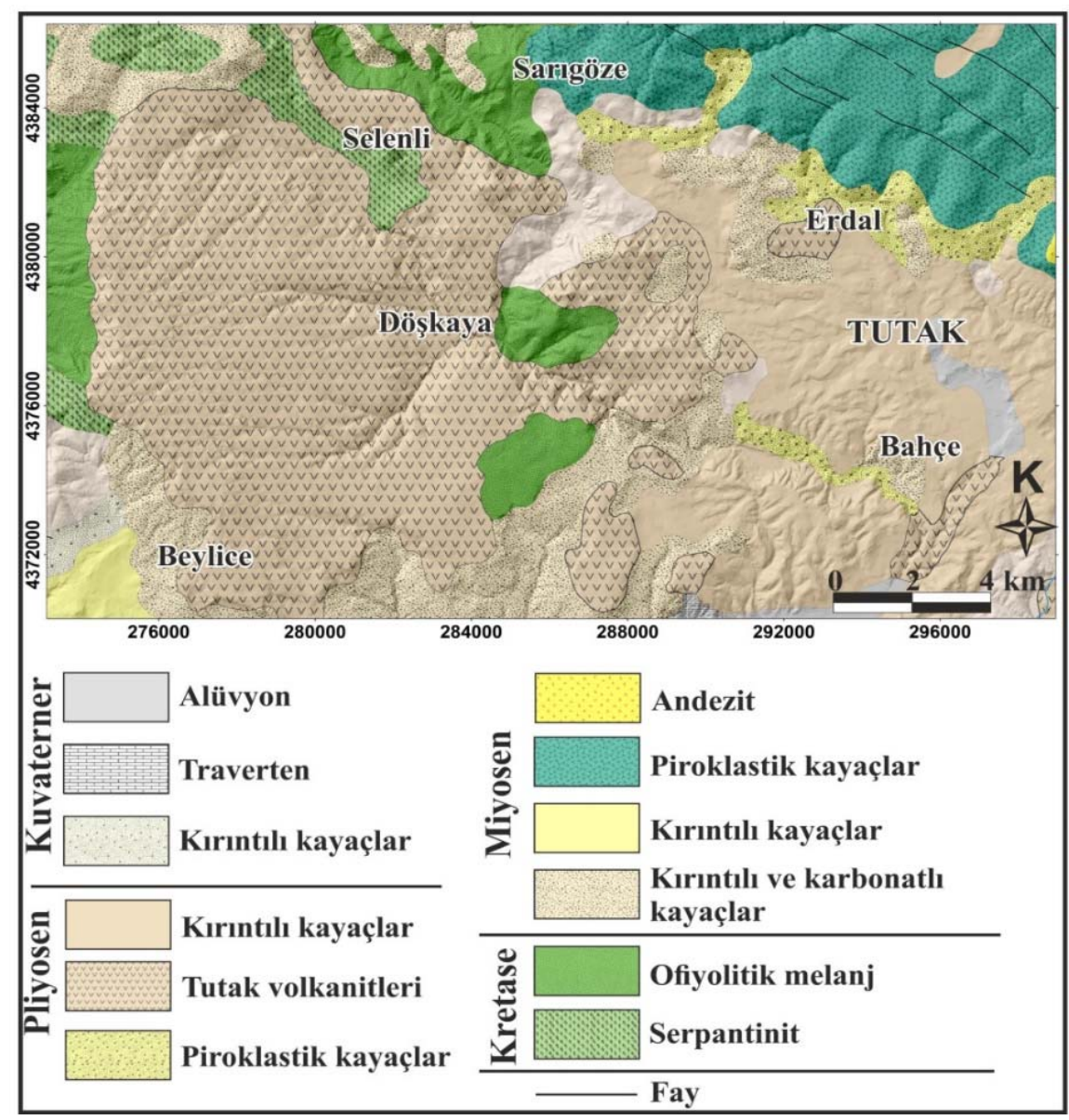

Şekil 2. Tutak volkanitlerinin yayılım alanını gösteren jeoloji haritası (MTA 1/500000 ölçekli jeoloji haritasından değiştirilerek alınmıştır) 
Tutak ve çevresindeki alanlardan püskürmüş olan mafik volkanik lavların Paleozoyik yaşlı metamorfik şistleri [24], Miyosen yaşlı kırıntılı kayaçları [25] ve Miyosen-Pliyosen yaşlı Ağırkaya kalderasına ait piroklastik kayaçları [26] örttüğü ve bu birimleri üzerlediği belirlenmiştir (Şekil 2). Çalışma alanında geniş alanlarda ve özellikle düzlük alanlarda mostraları gözlenebilen PliyosenKuvaterner yaşlı Bulanık formansyonunu, Tutak volkanitleri uyumsuzlukla örtmektedir [25]. Lokal olarak püskürmüş olan lavlar, hem Ağırkaya kalderasının yamaçlarında hem de Patnos ovasındaki geniş düzlük üzerinde küçük volkanik merkezler oluşturmuşlardır (Şekil 4).

Blok lav akıntıları şeklinde gözlenen bu lavlar çoğunlukla çok ince taneli, masif ve temiz lav serileri şeklinde gözlenirken, bazı lokasyonlardaki örneklerinde prizmatik feldispat minerallerinin kristalleri an fazla: $0,5 \mathrm{~cm}$ kadar görülebilmektedir.

\section{MINERALOJİ-PETROGRAFI}

Tutak volkanitlerine ait lavların ana mineralojik bileşimlerini plajiyoklaz, olivin, klinopiroksen ve opak mineralleri (Şekil 3) oluşturmakta fakat farklı dokusal karakteristikler sunmaktadırlar. Plajiyoklaz kristalleri kayaçlar içinde hem fenokristal hem de mikrolit formunda olup, prizmatik ve polisentetik ikiz özellikleriyle tipiktirler. Hem Fenokristal hem de ufak taneler halinde kristallenmiş olan olivin mineralleri çoğu kayaç içinde kenarlarından veya çatlaklarından itibaren iddingsitleşmişlerdir. Klinopiroksen mineralleri soluk pembemsi renkleri ile titanojit bileşimindedirler ve hem fenokristal hemde mikrofenokirstal formundadırlar. Dokusal olarak intersertal ve hipokristalin porfirik doku kayaçlarda genel olarak hakim dokuları oluştururken, kayaçların hamuru aynı minerallerin mikrolitleri ve vokanik camdan meydana gelmektedir. Bu bazaltik lavların bazı kesitlerinde plajiyoklaz kristallerinin uzun eksenleri boyunca paralel dizilimi ile ortaya çıkan akma dokusu ve bazı kesitlerde subofitik dokuda gözlemlenmiştir.
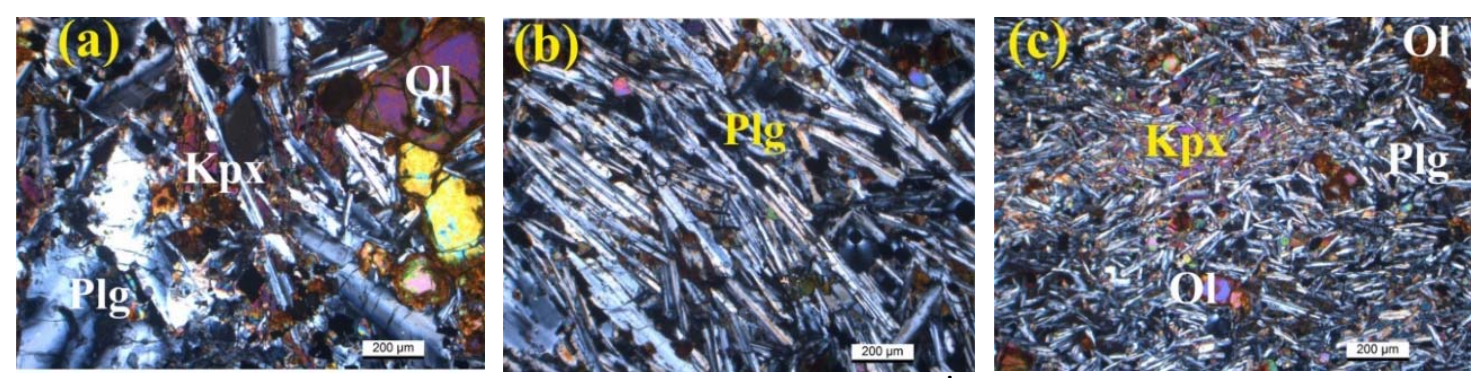

Şekil 3. Lavların incekesitlerine ait mikroskop görüntüleri. a) İddingsitleşmiş olivin, plajiyoklaz ve titanojit fenokristalleri intersertal hamur içinde dağılmakta. b) plajiyoklaz mikrolitlerinin oluşturduğu akma dokusu. c) Klinopiroksen minerali üzerinde plajiyoklaz mikrolitlerinin dağılması ile oluşan subofitik doku

\section{JEOKİMYA}

\subsection{Ana Element Jeokimyası}

Kayaç örneklerinin LOI içerikleri 0 ile 0,8 arasında değişmekte olup, alterasyondan etkilenmedikleri söylenebilir. Kayaçların $\mathrm{SiO}_{2}$ içerikleri \%46,70 ile 49,72 arasında, $\mathrm{MgO}$ içerikleri \%4,95 ile 8,92 arasında ve $\mathrm{Mg \#}$ değerleri 0,62 ile 0,71 arasında değişmektedir. Toplam alkali $\left(\mathrm{Na}_{2} \mathrm{O}+\mathrm{K}_{2} \mathrm{O}\right)-$ Silis $\left(\mathrm{SiO}_{2}\right)$ kayaç sınıflama diyagramında [27] Tutak volkanitlerine ait lavlar bazalt bileşimdedirler ve alkali-subalkali ayırtman çizgisi üzerine iz düşmektedirler (Şekil 4a). $\mathrm{SiO}_{2}-\mathrm{K}_{2} \mathrm{O}$ değişim diyagramı üzerinde bazaltik lavların tamamı düşük ve orta K'lu seriler alanına iz düşmektedirler (Şekil 4b).

Tutak volkanitlerinin $\mathrm{SiO}_{2}$ ve $\mathrm{MgO}$ değerleri çok dar bir aralıkta değişmekte ve hem $\mathrm{SiO}_{2}$ hem de $\mathrm{MgO}$ değerlerine karşı ana oksitlerin kullanıldığı harker değişim diyagramlarında evrimleşme 
süreçlerine işaret edecek herhangi bir değişim gözlenmemektedir. $\mathrm{Bu}$ nedenle harker değişim

(a)

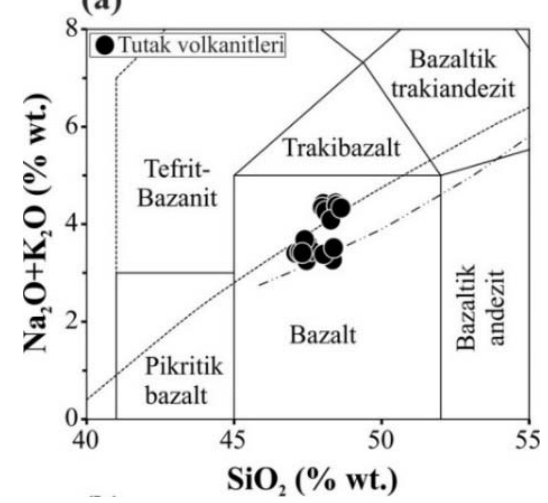

diyagramları makale içinde kullanılmamıştır.

(b)

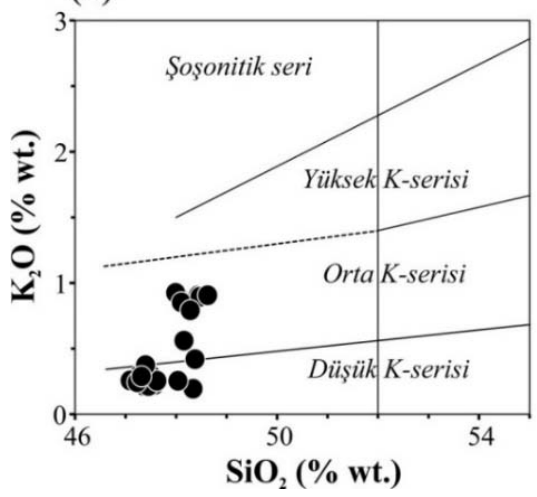

Şekil 4. Tutak volkanitlerine ait kayaçların (a) TAS (Toplam alkali-silis) sınıflama diyagramı [27], (b) $\mathrm{SiO}_{2}-\mathrm{K}_{2} \mathrm{O}$ diyagramı [29]. IB [30] ve $\mathrm{K}$ [31] alkali subalkali ayrım çizgilerini yansitmaktadır

\section{2. İz Element Jeokimyası}

Tutak volkanitlerine ait lavların $\mathrm{SiO}_{2}$ ve $\mathrm{MgO}$ karşı iz element değişim diyagramlarında da, ana element oksitlerinde olduğu gibi evrimleşme süreçlerine işaret edebilecek hiçbir negatif veya pozitif eğilim gözlenmemiş ve örneklerin $\mathrm{MgO}$ ve $\mathrm{SiO}_{2}$ 'ye karşı tamamen düzensiz dağıldıkları görülmüștür. $\mathrm{Bu}$ nedenle iz elementlerin Harker değişim diyagramlarıda makale içinde sunulmamıştır.

Tutak volkanitlerine ait bazaltik kayaçların iz element değişimlerini görmek amacıyla Sun ve McDonough [32]'un N-tipi MORB değerlerine normalize edilmiş olan çoklu element örümcek diyagramları üretilmiş̧ir (Şekil 5). Şekil 5a'da sunulmuş olan örümcek diyagram incelendiği zaman Bu diyagramlarda bazaltik lav örneklerinin tamamının büyük iyon yarıçaplı litofil (BIYYL) elementler ve hafif nadir toprak elementlerce (HNTE) yüksek alan şiddetli (YAŞ) elementlere göre belirgin bir şekilde zenginleştikleri gözlenmektedir. Diyagram üzerinde $\mathrm{Nb}$, Ta gibi YAŞ elementlerin komşu BIYL ve HNT elementlere göre tüketilmesi tipiktir. Bir diğer dikkate değer veri ise, $\mathrm{Y}$ ve $\mathrm{Yb}$ elementlerinin MORB değerlerine göre tüketilmesi ve negatif eğilim sergilemeleridir.

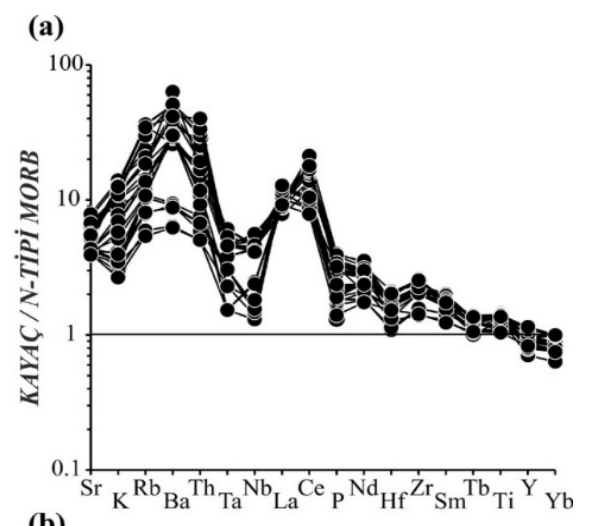

(b)

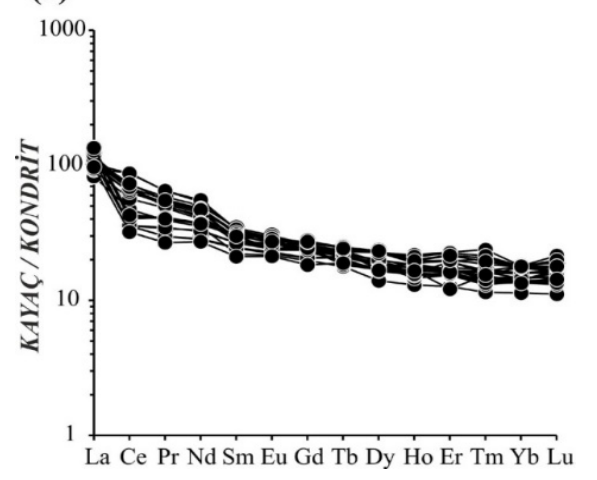

Şekil 5. Tutak volkanitlerine ait bazaltik kayaçların (a) N-tipi MORB değerlerine normalize ve (b) Kondrit değerlerine normalize örümcek diyagramları 
Tutak volkanitlerinin nadir toprak element değişimlerini görmek için Sun ve McDonough'un [32] Kondrit değerlerine normalize edilmiş NTE örümcek diyagramları Şekil 5b'de verilmiştir. Tüm bazaltik lav serilerinde HNT elementlerin ağır nadir toprak elementlere (ANTE) göre kısmen zenginleşmesi gözlenmektedir. $\mathrm{Bu}$ zenginleşme yaklaşık 10 kat olmakla birlikte lavların kondrit değerlerine normalize La (HNT)/Yb (ANTE) değerleri 6,6 ile 8,2 arasında değişim göstermektedir. Tüm örnekler için orta nadir toprak elementler (ONTE) ve ANTE'ler kondrit değerlerine paralel eğilim sunmakta ve ONTE değerlerinden ANTE değerlerine doğru herhangi bir fraksiyonlanma eğilimi göstermemektedirler. Kondrite normalize Dy (ONTE)/Yb (ANTE) değerleri 1,11 ile 1,24 arasında değişmektedir.

\subsection{Sr-Nd İzotop Jeokimyası}

Tutak volkanitlerine ait bazaltik lav örneklerinin $\mathrm{Sr}$ ve Nd izotopik oranları elde edilmiş ve Çizelge 1'de verilmiştir. Bazaltik kayaçların ${ }^{87} \mathrm{Sr} /{ }^{86} \mathrm{Sr}_{(i)}$,
${ }^{143} \mathrm{Nd} /{ }^{144} \mathrm{Nd}_{(i)}$ ve $\varepsilon \mathrm{Nd}$ oranları sirasiyla 0,704040 $0,704841, \quad 0,512785-0,512826$ ve $3,12-3,84$ arasında değişim sergilemektedirler. En primitif bazaltik örneklerden düşük $\mathrm{MgO}$ değerli örneklere gittikçe $\mathrm{Sr}$ izotopik değerlerinde artış ve $\mathrm{Nd}$ izotopik değerlerinde düşüş gözlenmektedir.

Şekil 6' da örneklerin ${ }^{87} \mathrm{Sr} /{ }^{86} \mathrm{Sr}_{(i)}$ izotopik oranlarına karş1 ${ }^{143} \mathrm{Nd} /{ }^{144} \mathrm{Nd}_{(i)}$ izotopik oranlarının kullanıldığ 1 değişim diyagramı üretilmiştir. Şekil 6'daki izotopik değişimler incelendiği zaman örneklerin manto alanı içinde ve tüketilmiş alanda yer aldığı gözlenmektedir. Örneklerin bu diyagram üzerindeki eğilimleri en primitif bazaltik örneklerden daha evrimleșmiş ve $\mathrm{MgO}$ değerleri düşük olan örneklere geçtikçe kıtasal sediment değerlerine ve GLOSS (Global subducted sediment; global ölçekte dalmış sediment) alanına doğru yönelim sergilemektedir. Örneklerin GLOSS alanının doğru yönelim sergilemeleri, kaynak alanda zenginleşmiş bir manto kaynak alanının veya kıtasal kirlenmenin etkilerinin var olabileceğine işaret etmektedir.

Çizelge 1. Tutak volkanitlerine ait seçilmiş lavların ana oksit, iz element, nadir toprak element ve izotop analiz sonuçları

\begin{tabular}{|c|c|c|c|c|c|c|c|c|c|c|c|c|}
\hline Örnek No & TUT-1 & TUT-2 & TUT-3 & TUT-4 & TUT-5 & TUT-6 & TUT-7 & TUT-8 & TUT-9 & TUT-10 & TUT-11 & TUT-12 \\
\hline Kayaç tipi & Bazalt & Bazalt & Bazalt & Bazalt & Bazalt & Bazalt & Bazalt & Bazalt & Bazalt & Bazalt & Bazalt & Bazalt \\
\hline $\mathrm{SiO}_{2} \%$ & 47,18 & 47,47 & 46,70 & 47,28 & 47,53 & 46,80 & 47,56 & 47,69 & 47,85 & 47,58 & 47,47 & 47,68 \\
\hline $\mathrm{TiO}_{2}$ & 1,70 & 1,75 & 1,72 & 1,75 & 1,70 & 1,71 & 1,38 & 1,35 & 1,39 & 1,40 & 1,37 & 1,36 \\
\hline $\mathrm{Al}_{2} \mathrm{O} 3$ & 16,87 & 16,80 & 16,78 & 16,84 & 16,90 & 16,50 & 16,58 & 16,64 & 16,45 & 16,31 & 16,78 & 16,61 \\
\hline $\mathrm{Fe}_{2} \mathrm{O}_{3}{ }^{\mathrm{TOT}}$ & 11,22 & 11,33 & 11,25 & 11,01 & 11,21 & 11,62 & 10,37 & 10,47 & 10,10 & 11,01 & 10,18 & 10,51 \\
\hline $\mathrm{MnO}$ & 0,18 & 0,18 & 0,18 & 0,18 & 0,18 & 0,17 & 0,17 & 0,17 & 0,16 & 0,15 & 0,15 & 0,15 \\
\hline $\mathrm{MgO}$ & 8,59 & 8,43 & 8,16 & 8,45 & 8,37 & 8,06 & 8,19 & 8,42 & 8,39 & 7,86 & 8,24 & 8,48 \\
\hline $\mathrm{CaO}$ & 10,42 & 10,15 & 10,54 & 10,65 & 10,33 & 10,54 & 10,02 & 9,79 & 9,75 & 10,05 & 10,05 & 9,75 \\
\hline $\mathrm{Na}_{2} \mathrm{O}$ & 3,10 & 3,28 & 3,09 & 3,05 & 3,18 & 3,01 & 3,46 & 3,35 & 3,47 & 3,65 & 3,37 & 3,37 \\
\hline $\mathrm{K}_{2} \mathrm{O}$ & 0,22 & 0,29 & 0,29 & 0,25 & 0,22 & 0,21 & 0,90 & 0,83 & 0,89 & 0,55 & 0,91 & 0,84 \\
\hline $\mathrm{P}_{2} \mathrm{O}_{5}$ & 0,21 & 0,24 & 0,24 & 0,19 & 0,26 & 0,15 & 0,35 & 0,32 & 0,32 & 0,21 & 0,36 & 0,33 \\
\hline$L O I$ & 0,0 & 0,0 & 0,8 & 0,0 & 0,0 & 0,8 & 0,7 & 0,6 & 0,9 & 0,8 & 0,8 & 0,5 \\
\hline Total & 99,69 & 99,92 & 99,75 & 99,65 & 99,88 & 99,57 & 99,68 & 99,63 & 99,67 & 99,57 & 99,68 & 99,58 \\
\hline$V(p p m)$ & 205 & 206 & 200 & 205 & 206 & 200 & 188 & 180 & 190 & 201 & 190 & 180 \\
\hline $\mathrm{Co}$ & 55,7 & 49,8 & 51,8 & 55,7 & 49,8 & 51,8 & 39,4 & 38,1 & 39,3 & 35,8 & 40,0 & 38,2 \\
\hline $\mathrm{Ni}$ & 99,5 & 93,8 & 91,3 & 99,5 & 93,8 & 91,3 & 95,0 & 114,1 & 99,0 & 56,0 & 95,5 & 113,9 \\
\hline$S r$ & 356,0 & 375,4 & 389,0 & 356,0 & 375,4 & 389,0 & 502,9 & 467,7 & 489,9 & 375,4 & 501,9 & 467,9 \\
\hline$R b$ & 3,0 & 5,8 & 4,5 & 3,0 & 5,8 & 4,5 & 20,3 & 16,7 & 19,2 & 7,9 & 20,0 & 16,8 \\
\hline$B a$ & 39 & 57 & 55 & 39 & 57 & 55 & 316 & 320 & 261 & 192 & 314 & 322 \\
\hline$T h$ & 0,6 & 0,8 & 0,8 & 0,6 & 0,8 & 0,8 & 3,6 & 4,0 & 4,8 & 1,3 & 3,5 & 4,0 \\
\hline$T a$ & 0,2 & 0,4 & 0,4 & 0,2 & 0,4 & 0,4 & 0,7 & 0,6 & 0,6 & 0,2 & 0,6 & 0,5 \\
\hline $\mathrm{Nb}$ & 3,0 & 3,4 & 3,6 & 3,0 & 3,4 & 3,6 & 10,7 & 9,7 & 9,5 & 5,7 & 10,5 & 9,9 \\
\hline$Z r$ & 165,0 & 189,9 & 186,2 & 165,0 & 189,9 & 186,2 & 166,5 & 149,3 & 149,3 & 114,8 & 166,0 & 149,0 \\
\hline$Y$ & 28,1 & 30,3 & 31,8 & 28,1 & 30,3 & 31,8 & 27,7 & 26,5 & 26,0 & 25,4 & 27,6 & 26,0 \\
\hline$H f$ & 3,3 & 3,9 & 4,1 & 3,3 & 3,9 & 4,1 & 3,7 & 3,5 & 2,7 & 2,2 & 3,6 & 3,3 \\
\hline$U$ & 0,2 & 0,4 & 0,4 & 0,2 & 0,4 & 0,4 & 1,1 & 1,1 & 1,1 & 0,2 & 1,1 & 1,1 \\
\hline$P b$ & 0,8 & 1,1 & 1,3 & 0,8 & 1,1 & 1,3 & 1,7 & 0,6 & 1,3 & 1,6 & 1,6 & 0,6 \\
\hline$L a$ & 7,5 & 9,9 & 9,3 & 7,5 & 9,9 & 9,3 & 23,2 & 21,3 & 21,5 & 9,9 & 23,0 & 21,1 \\
\hline $\mathrm{Ce}$ & 21,8 & 24,6 & 26,0 & 21,8 & 24,6 & 26,0 & 42,2 & 41,9 & 44,5 & 21,7 & 41,9 & 40,8 \\
\hline$P r$ & 3,26 & 3,87 & 3,79 & 3,26 & 3,87 & 3,79 & 4,67 & 4,77 & 5,20 & 2,80 & 4,67 & 4,72 \\
\hline
\end{tabular}


Tutak (Ăgrı) Volkanitlerinin Jeokimyast ve Petrolojisi: Amfibolce Zengin Granat Peridotitin Kısmi Ergimesi

\begin{tabular}{|c|c|c|c|c|c|c|c|c|c|c|c|c|}
\hline Nd & 15,1 & 17,4 & 17,1 & 15,1 & 17,4 & 17,1 & 19,9 & 19,1 & 21,7 & 13,3 & 19,7 & 19,3 \\
\hline$S m$ & 4,04 & 4,67 & 4,53 & 4,04 & 4,67 & 4,53 & 4,06 & 4,58 & 4,25 & 3,73 & 4,04 & 4,54 \\
\hline$E u$ & 1,49 & 1,65 & 1,57 & 1,49 & 1,65 & 1,57 & 1,40 & 1,38 & 1,39 & 1,31 & 1,38 & 1,36 \\
\hline$G d$ & 4,97 & 5,51 & 5,56 & 4,97 & 5,51 & 5,56 & 4,94 & 4,81 & 5,14 & 4,21 & 4,92 & 4,79 \\
\hline $\mathrm{Tb}$ & 0,88 & 0,92 & 0,90 & 0,88 & 0,92 & 0,90 & 0,71 & 0,83 & 0,83 & 0,79 & 0,68 & 0,81 \\
\hline Dy & 5,75 & 5,62 & 5,84 & 5,75 & 5,62 & 5,84 & 4,28 & 5,01 & 4,30 & 4,82 & 4,26 & 5,00 \\
\hline $\mathrm{Ho}$ & 1,09 & 1,18 & 1,10 & 1,09 & 1,18 & 1,10 & 0,88 & 1,03 & 1,01 & 0,88 & 0,86 & 1,01 \\
\hline$E r$ & 3,26 & 3,69 & 3,53 & 3,26 & 3,69 & 3,53 & 2,59 & 2,71 & 2,65 & 3,18 & 2,56 & 2,68 \\
\hline$T m$ & 0,47 & 0,54 & 0,49 & 0,47 & 0,54 & 0,49 & 0,36 & 0,42 & 0,41 & 0,40 & 0,34 & 0,39 \\
\hline$Y b$ & 2,96 & 3,01 & 3,01 & 2,96 & 3,01 & 3,01 & 2,42 & 3,00 & 2,44 & 2,67 & 2,39 & 2,98 \\
\hline$L u$ & 0,44 & 0,50 & 0,45 & 0,44 & 0,50 & 0,45 & 0,40 & 0,44 & 0,38 & 0,41 & 0,42 & 0,42 \\
\hline \multicolumn{13}{|l|}{ Izotop } \\
\hline $87 \mathrm{Sr} / 86 \mathrm{Sr}$ & 0,70404 & & 0,704483 & & & 0,704567 & & & & 0,70458 & & \\
\hline $143 N d / 144 N d$ & 0,51283 & & 0,512826 & & & 0,512798 & & & & 0,51282 & & \\
\hline$\varepsilon N d$ & 3,74 & & 3,66 & & & 3,12 & & & & 3,55 & & \\
\hline
\end{tabular}

Çizelge 1 (Devam)

\begin{tabular}{|c|c|c|c|c|c|c|c|c|c|c|c|c|}
\hline Örnek No & TUT-13 & TUT-14 & TUT-15 & TUT-16 & TUT-17 & TUT-18 & TUT-19 & TUT-20 & TUT-21 & TUT-22 & TUT-23 & TUT-24 \\
\hline Kayaç tipi & Bazalt & Bazalt & Bazalt & Bazalt & Bazalt & Bazalt & Bazalt & Bazalt & Bazalt & Bazalt & Bazalt & Bazalt \\
\hline $\mathrm{SiO}_{2} \%$ & 47,89 & 46,77 & 47,32 & 47,58 & 46,55 & 47,08 & 47,35 & 47,81 & 48,01 & 48,18 & 47,99 & 46,73 \\
\hline $\mathrm{TiO}_{2}$ & 1,41 & 1,75 & 1,69 & 1,71 & 1,69 & 1,73 & 1,77 & 1,37 & 1,39 & 1,62 & 1,75 & 1,69 \\
\hline $\mathrm{Al}_{2} \mathrm{O3}$ & 16,55 & 16,82 & 16,78 & 16,75 & 16,73 & 16,84 & 16,85 & 16,68 & 16,61 & 16,87 & 16,77 & 16,58 \\
\hline $\mathrm{Fe}_{2} \mathrm{O}_{3}{ }^{\mathrm{TOT}}$ & 9,85 & 11,15 & 11,11 & 11,43 & 11,14 & 11,15 & 11,18 & 10,41 & 10,10 & 11,25 & 11,45 & 11,31 \\
\hline $\mathrm{MnO}$ & 0,19 & 0,17 & 0,22 & 0,21 & 0,18 & 0,21 & 0,23 & 0,16 & 0,15 & 0,23 & 0,18 & 0,21 \\
\hline $\mathrm{MgO}$ & 8,42 & 8,20 & 8,60 & 8,38 & 8,41 & 8,63 & 8,47 & 8,45 & 7,35 & 7,21 & 7,79 & 8,10 \\
\hline $\mathrm{CaO}$ & 9,80 & 10,41 & 10,51 & 10,16 & 10,52 & 10,41 & 10,14 & 9,73 & 10,44 & 10,67 & 10,36 & 10,49 \\
\hline $\mathrm{Na}_{2} \mathrm{O}$ & 3,43 & 3,01 & 3,02 & 3,18 & 3,10 & 3,16 & 3,29 & 3,25 & 3,37 & 3,05 & 3,11 & 3,07 \\
\hline $\mathrm{K}_{2} \mathrm{O}$ & 0,88 & 0,25 & 0,21 & 0,25 & 0,25 & 0,24 & 0,37 & 0,78 & 0,89 & 0,19 & 0,25 & 0,28 \\
\hline $\mathrm{P}_{2} \mathrm{O}_{5}$ & 0,34 & 0,23 & 0,22 & 0,23 & 0,25 & 0,20 & 0,22 & 0,35 & 0,39 & 0,37 & 0,22 & 0,27 \\
\hline LOI & 0,9 & 0,9 & 0,0 & 0,0 & 0,7 & 0,0 & 0,0 & 0,6 & 0,9 & 0,0 & 0,0 & 0,8 \\
\hline Total & 99,69 & 99,73 & 99,73 & 99,73 & 99,73 & 99,73 & 99,73 & 99,69 & 99,69 & 99,73 & 99,73 & 99,73 \\
\hline$V(p p m)$ & 187 & 202 & 204 & 205 & 200 & 205 & 206 & 180 & 190 & 205 & 206 & 200 \\
\hline $\mathrm{Co}$ & 39,0 & 51,0 & 55,0 & 50,4 & 51,8 & 55,7 & 49,8 & 38,1 & 39,3 & 55,7 & 49,8 & 51,8 \\
\hline $\mathrm{Ni}$ & 99,3 & 91,0 & 99,0 & 94,2 & 91,3 & 99,5 & 93,8 & 114,1 & 99,0 & 99,5 & 93,8 & 91,3 \\
\hline$S r$ & 491,8 & 395,0 & 356,4 & 376,0 & 389,0 & 356,0 & 375,4 & 467,7 & 489,9 & 356,0 & 375,4 & 389,0 \\
\hline$R b$ & 19,1 & 4,4 & 3,3 & 6,1 & 4,5 & 3,0 & 5,8 & 16,7 & 19,2 & 3,0 & 5,8 & 4,5 \\
\hline$B a$ & 260 & 57 & 40 & 59 & 55 & 39 & 57 & 320 & 261 & 39 & 57 & 55 \\
\hline$T h$ & 4,6 & 0,7 & 0,6 & 0,9 & 0,8 & 0,6 & 0,8 & 4,0 & 4,8 & 0,6 & 0,8 & 0,8 \\
\hline$T a$ & 0,6 & 0,4 & 0,3 & 0,4 & 0,4 & 0,2 & 0,4 & 0,6 & 0,6 & 0,2 & 0,4 & 0,4 \\
\hline $\mathrm{Nb}$ & 9,7 & 3,8 & 3,2 & 3,7 & 3,6 & 3,0 & 3,4 & 9,7 & 9,5 & 3,0 & 3,4 & 3,6 \\
\hline$Z r$ & 151,0 & 186,7 & 165,2 & 190,2 & 186,2 & 165,0 & 189,9 & 149,3 & 149,3 & 165,0 & 189,9 & 186,2 \\
\hline$Y$ & 27,0 & 31,4 & 28,4 & 30,8 & 31,8 & 28,1 & 30,3 & 26,5 & 26,0 & 28,1 & 30,3 & 31,8 \\
\hline$H f$ & 2,6 & 4,2 & 3,1 & 4,1 & 4,1 & 3,3 & 3,9 & 3,5 & 2,7 & 3,3 & 3,9 & 4,1 \\
\hline$U$ & 1,1 & 0,4 & 0,2 & 0,4 & 0,4 & 0,2 & 0,4 & 1,1 & 1,1 & 0,2 & 0,4 & 0,4 \\
\hline$P b$ & 1,4 & 1,3 & 0,9 & 1,2 & 1,3 & 0,8 & 1,1 & 0,6 & 1,3 & 0,8 & 1,1 & 1,3 \\
\hline$L a$ & 22,0 & 9,5 & 7,7 & 10,0 & 9,3 & 7,5 & 9,9 & 21,3 & 21,5 & 7,5 & 9,9 & 9,3 \\
\hline $\mathrm{Ce}$ & 45,0 & 26,3 & 21,6 & 25,0 & 26,0 & 21,8 & 24,6 & 41,9 & 44,5 & 21,8 & 24,6 & 26,0 \\
\hline$P r$ & 5,24 & 3,84 & 3,23 & 3,89 & 3,79 & 3,26 & 3,87 & 4,77 & 5,20 & 3,26 & 3,87 & 3,79 \\
\hline $\mathrm{Nd}$ & 21,4 & 17,4 & 15,3 & 17,2 & 17,1 & 15,1 & 17,4 & 19,1 & 21,7 & 15,1 & 17,4 & 17,1 \\
\hline$S m$ & 4,21 & 4,56 & 4,06 & 4,65 & 4,53 & 4,04 & 4,67 & 4,58 & 4,25 & 4,04 & 4,67 & 4,53 \\
\hline$E u$ & 1,36 & 1,55 & 1,52 & 1,64 & 1,57 & 1,49 & 1,65 & 1,38 & 1,39 & 1,49 & 1,65 & 1,57 \\
\hline$G d$ & 5,11 & 5,59 & 4,99 & 5,41 & 5,56 & 4,97 & 5,51 & 4,81 & 5,14 & 4,97 & 5,51 & 5,56 \\
\hline$T b$ & 0,79 & 0,92 & 0,85 & 0,91 & 0,90 & 0,88 & 0,92 & 0,83 & 0,83 & 0,88 & 0,92 & 0,90 \\
\hline$D y$ & 4,26 & 5,87 & 5,71 & 5,67 & 5,84 & 5,75 & 5,62 & 5,01 & 4,30 & 5,75 & 5,62 & 5,84 \\
\hline $\mathrm{Ho}$ & 1,03 & 1,12 & 1,06 & 1,22 & 1,10 & 1,09 & 1,18 & 1,03 & 1,01 & 1,09 & 1,18 & 1,10 \\
\hline$E r$ & 2,62 & 3,56 & 3,22 & 3,74 & 3,53 & 3,26 & 3,69 & 2,71 & 2,65 & 3,26 & 3,69 & 3,53 \\
\hline $\mathrm{Tm}$ & 0,39 & 0,52 & 0,51 & 0,60 & 0,49 & 0,47 & 0,54 & 0,42 & 0,41 & 0,47 & 0,54 & 0,49 \\
\hline$Y b$ & 2,41 & 3,03 & 2,94 & 3,03 & 3,01 & 2,96 & 3,01 & 3,00 & 2,44 & 2,96 & 3,01 & 3,01 \\
\hline$L u$ & 0,36 & 0,48 & 0,41 & 0,54 & 0,45 & 0,44 & 0,50 & 0,44 & 0,38 & 0,44 & 0,50 & 0,45 \\
\hline \multicolumn{13}{|l|}{ Izotop } \\
\hline $87 \mathrm{Sr} / 86 \mathrm{Sr}$ & & & & & & & & & 0,70476 & 0,70458 & 0,70472 & \\
\hline $143 N d / 144 N d$ & & & & & & & & & 0,51282 & 0,51280 & 0,51283 & \\
\hline$\varepsilon N d$ & & & & & & & & & 3,55 & 3,27 & 3,84 & \\
\hline
\end{tabular}




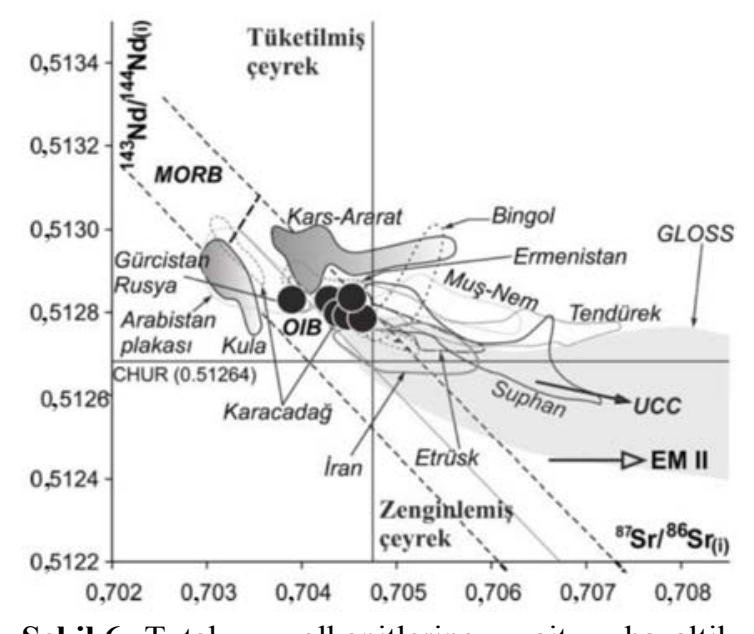

Şekil 6. Tutak volkanitlerine ait bazaltik örneklerin izotopik değişim diyagramları. Diyagram üzerinde verilmiş olan ve volkanik alanları temsil eden alanlar Özdemir ve Güleç [20] ve Oyan ve arkadaşları [7,21]'den elde edilmiş ve diyagram üzerine iz düşürülmüştür

\section{TARTIŞMA}

\subsection{Fraksiyonel Kristallenme ve Kitasal Kirlenme Süreçleri}

Tutak volkanitlerine ait bazaltik lavların $\mathrm{SiO}_{2}$ içerikleri \%46,55 ile 48,81 arasında, $\mathrm{MgO}$ içerikleri \% 7,21 ile 8,92 arasında ve $\mathrm{Mg \#} \mathrm{değerleri}$ 0,62-0,71 arasında değişim göstermektedirler. Ana oksit ve iz elementlerin $\mathrm{MgO}$ ve $\mathrm{SiO}_{2}$ değerlerine karşı değişimleri, magma odasında veya kıtasal seviyelerde fraksiyonel kristallenmenin izlerini taşıyabilecek negatif veya pozitif eğilimler üretmemiş ve tamamen örneklerin ya yatay ya da saçılmış halde iz düştükleri gözlemlenmiştir. $\mathrm{Bu}$ veriler Tutak volkanitlerini oluşturan magma odası veya odalarında fraksiyonel kristallenmenin olmadığını veya çok düşük derecede göz ardı edilebilir düzeyde olabileceğine işaret etmektedir.

$\mathrm{Bu}$ veriler fraksiyonel kristallenmenin örneklerin evriminde etkili bir süreç olmadığına işaret etse de, bazaltik lavlar için yüksek $\mathrm{MgO}$ değerli lavlardan düşük $\mathrm{MgO}$ içerikli lavlara doğru yükselen $\mathrm{Sr}$ ve düşen $\mathrm{Nd}$ bileşimleri bu lavların kıtasal kirlenmeye maruz kalabilecekleri yönünde ipuçları vermektedir. İlksel magmalara göre kitasal kabuğun ${ }^{143} \mathrm{Nd} /{ }^{144} \mathrm{Nd}$ izotop konsantrasyonlar1 daha düşük iken, ${ }^{87} \mathrm{Sr} /{ }^{86} \mathrm{Sr}$ izotopik oranları daha yüksektir. $\mathrm{MgO}$ oranları düşük ve primitif lavlara göre daha fazla evrimleşmiş olan lavların $\mathrm{Sr}$ izotopik değerleri ilksel lavlarına göre daha yüksek ve Nd izotopik oranları daha düşüktür. Bu izotopik oranlar Tutak volkanitlerinin evriminde AFC süreçlerinin etkili olabileceğine işaret etmektedir. Kitasal kirlenmenin etkilerini görebilmek amaciyla Şekil 7'de izotop, iz element ve MgO içeriklerinin kullanıldığı diyagramlar üretilmiştir.
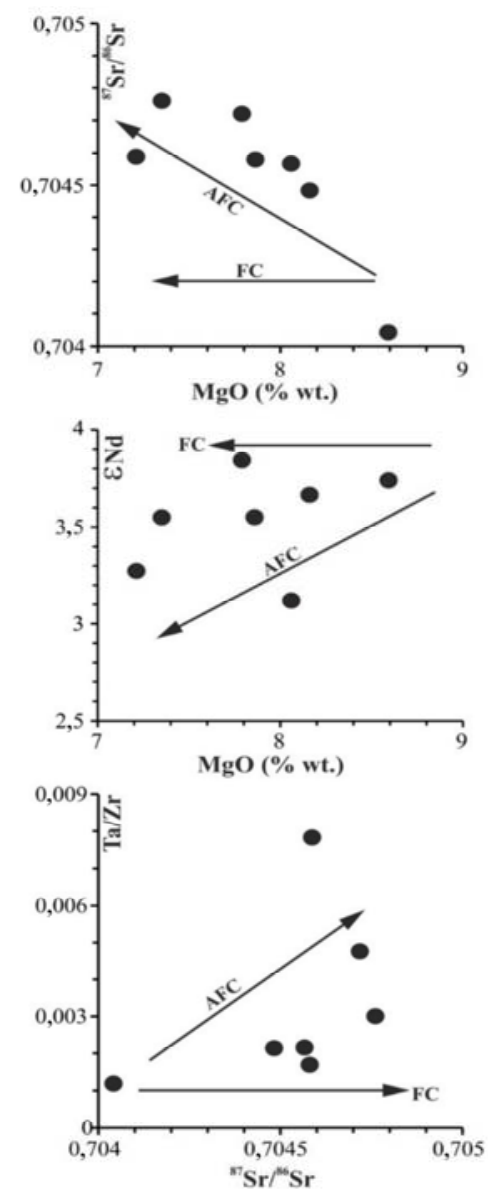

Şekil 7. Örneklerin $\mathrm{MgO}$ değerlerine karşı $\varepsilon N d$ ve ${ }^{87} \mathrm{Sr} /{ }^{86} \mathrm{Sr}$ diyagramları ile $\mathrm{Sr}$ izotop değerlerine karşı Ta/Zr ikili değişim diyagramları. AFC: Asimilasyonla birleşik kristal ayrımlaşması, FC: kristal ayrımlaşması 
Şekil 7'de verilmiş olan MgO'e karşı $\mathrm{Sr}$ ve $\varepsilon \mathrm{Nd}$ izotop değerleri ile ${ }^{87} \mathrm{Sr} /{ }^{86} \mathrm{Sr}$ 'ya karşı $\mathrm{Ta} / \mathrm{Zr}$ iz element oranları arasındaki ilişki AFC süreçlerinin magma odası veya odalarının evriminde önemli olabileceğini ve dolayısıyla kıtasal kirlenmenin varlığını ortaya koymaktadır. $\mathrm{MgO}$ değerleri düşük olan ve primitif bazaltik lavlara göre evrimleşmiş lav serilerinde gözlenen yükselen $\mathrm{Sr}$ ve düşen $\varepsilon \mathrm{Nd}$ izotop değerleri ve yükselen ${ }^{87} \mathrm{Sr} /{ }^{86} \mathrm{Sr}$ değerlerine karşı yükselen $\mathrm{Ta} / \mathrm{Zr}$ iz element oranları kıtasal kirlenmenin izlerini yansıtmaktadır.

Kitasal kirlenmenin ve AFC süreçlerinin izlerini net olarak görebilmek amaciyla Bohrson ve Spera [34] ve Spera ve Bohrson [35] tarafından önerilmiş olan EC-AFC kodu kullanılarak petrolojik modeller üretilmiştir (Şekil 8). $\mathrm{Bu}$ modellemelerde, AFC izlerinin lavlar üzerindeki en tipik etkilerini görebilmek amacıyla $\mathrm{Sr}$ ve $\mathrm{Nd}$ izotopik değerleri kullanılmıştır. Detayları Bohrson ve Spera [34]'de verilmiş olan EC-AFC model eğrilerinin oluşturulmasında, primitif uç üye olarak, TUT-1 nolu örnek kullanılmıştır. Doğu Anadolu bölgesi ve özellikle çalışma alanında kitasal kirletici olabilecek temel birimlerden herhangi bir izotopik veya iz element verisi elde edilemediğinden dolayı Taylor ve McLennan [36]'ın üst kıtasal kabuk ve alt kıtasal kabuk için önermiş oldukları Sr ve Nd izotopik değerleri, modellemelerde kitasal kirletici olarak kullanılmıştır.

EC-AFC modellemesi, lav örnekleri için en uygun petrolojik model eğrisi elde edilinceye kadar tekrar edilmiş ve en uygun eğri elde edildiğinde modelleme durdurulmuştur. $\mathrm{Bu}$ modellemelerde primitif (ilksel) magma ve kitasal kabuğun başlangıç sıcaklıkları sırasıyla $1300-1000{ }^{\circ} \mathrm{C}$ ve $600-300{ }^{\circ} \mathrm{C}$ arasında değiştirilmiştir. Şekil 10 'da görüleceği üzere Tutak volkanitlerine ait bazaltik lavlar alt kıtasal kabuk değerleri ile elde edilen eğriden ziyade, üst kıtasal kabuğun iz element ve izotopik verileri ile elde edilmiş EC-AFC eğrisi üzerine iz düşmekte ve bu eğriye doğru yönelmektedir. Model sonuçları volkanizmayı üreten magma odasının max: $\% 3$ değerine kadar kıtasal kabuğu özümsediğini ve $\mathrm{MgO}$ değerleri düşük bazaltik lavlar için kitasal kirlenme süreçlerinin önemli olabileceğine işaret etmektedir
(Şekil 8). Tüm bu veriler bazaltik lavların fraksiyonel kristallenmeden daha baskın olarak kıtasal kirlenme ile evrimleşmiş olabileceğini ortaya koymaktadir.

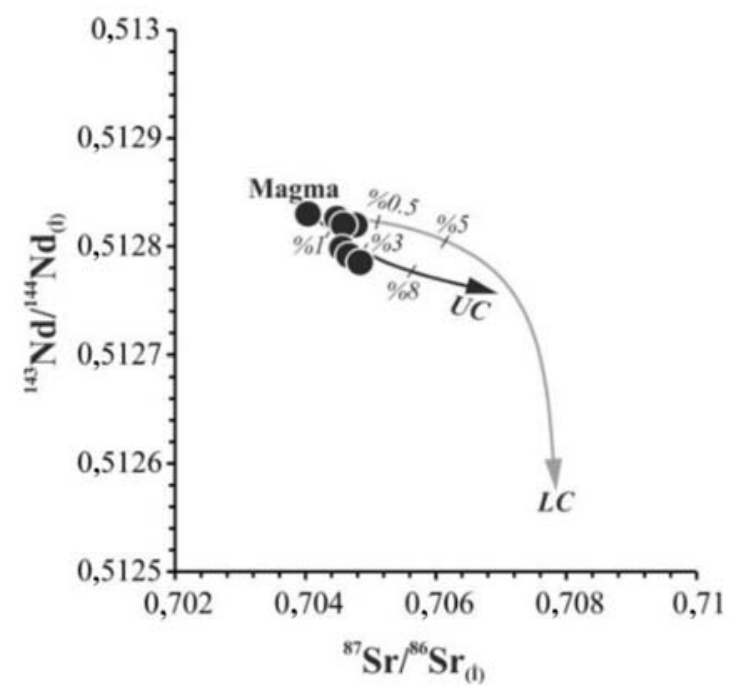

Şekil 8. Tutak volkanitleri için EC-AFC kodu kullanılarak oluşturulmuş olan model eğrileri. Termal parametreler Bohrson ve Spera [34]'den, kıtasal üst ve alt kabuk iz element ve izotop değerleri Taylor ve McLennan [36]'den alınmıştır. En uygun model eğrisi magma için başlangıç ve liquid sicaklığı üt kabuk için $1280{ }^{\circ} \mathrm{C}$ ve alt kabuk için $1320{ }^{\circ} \mathrm{C}$ alındığı zaman oluşturulmuş ve kitasal kabuğun başlangıç sıcaklığ 1 üst kabuk için $300{ }^{\circ} \mathrm{C}$ ve alt kabuk için $600{ }^{\circ} \mathrm{C}$ derece alındığ 1 zaman elde edilebilmiştir

\subsection{Manto Kaynak Alanı ve Zenginleşmeler}

Tutak volkanitlerine ait bazaltik lavların MORB'a normalize uyumsuz element örümcek diyagramlarında (Şekil 5a) BİYL ve HNT elementlerin YAŞ elementlere göre zenginleşme sergilemesi, bu lavların manto kaynak alanında yitim bileşeninin (dalan okyanusal litosferin) etkilerini veya AFC izlerini yansitmaktadır. Bu negatif eğilim ve YAŞ elementlerin tüketilmesi, $\mathrm{MgO}$ içeriği yüksek olan ve AFC süreçlerinden etkilenmemiş örnekler için manto kaynak alanında yitim bileşeni ile zenginleşme süreçlerine işaret 
etmektedir. Bunun yanı sıra, $\mathrm{MgO}$ değerleri primitif bazaltik lavlara göre düşük olan örneklerde ise bu eğilim EC-AFC modellemeleriyle de belirgin olarak gözlenen AFC süreçlerinin izlerini yansıtmaktadır. Okyanus ortası sırt bazaltları (MORB) ve okyanus adası bazalt (OIB) ortamlarından püsküren primitif ilksel bazaltik lavlar, MORB veya primitif manto değerlerine normalize edilmiş uyumsuz element örümcek diyagramlarında $\mathrm{Nb}$ ve Ta gibi YAŞ element içeriği bakımından komşu La, Ce (HNTE) veya $\mathrm{Th}, \mathrm{Ba}$ (BIYL) elementlerine göre zenginleşme sergilerler [37]. Bunun yanı sıra, fraksiyonel kristallenme veya kitasal kirlenme süreçlerinden etkilenmemiş ve primitif kaynaklara

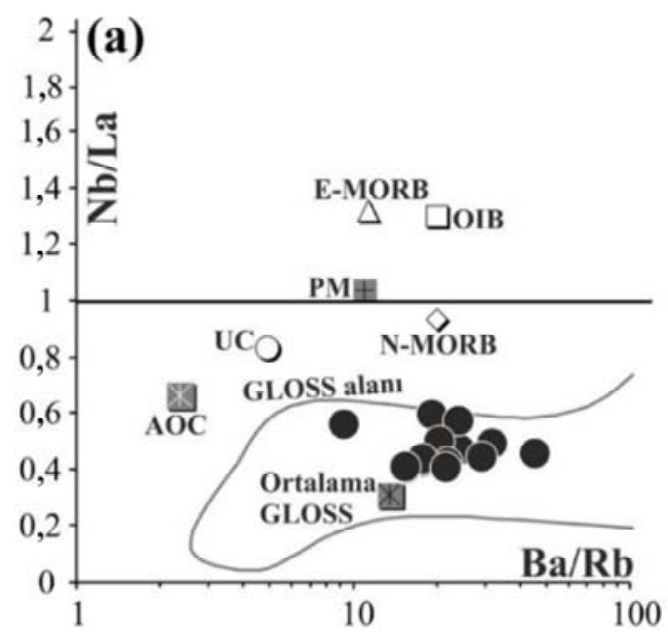

işaret eden bazaltik lavlarda komşu BİYL ve HNT elementlere göre $\mathrm{Nb}$ ve $\mathrm{Ta}$ elementlerinin tüketilme sergilemesi manto kaynak alanının yitim bileşeni ile zenginleştiğine işaret eder [37-40]. $\mathrm{MgO}$ içeriği yüksek bazaltik lavlarda gözlenen $\mathrm{Nb}$ ve Ta fakirleşmesi, OIB veya MORB tipi kaynaklardan ziyade, yitim bileşeni ile zenginleşmiş manto kaynak alanlarından bu lavların türeyebileceğine işaret etmektedir. Tutak volkanitlerine ait bazaltik lavları oluşturan manto kaynak alanlarının zenginleşme süreçlerini ortaya koyma amaciyla Wang ve arkadaşları [41]'nın $\mathrm{Ba} / \mathrm{Rb}$ 'a karşı $\mathrm{Nb} / \mathrm{La}$ ve Hasti ve arkadaşları [42] tarafından üretilmiş olan $\mathrm{Ce} / \mathrm{Ce}$ *Nd ye karşı $\mathrm{Nb} / \mathrm{La}$ değişim diyagramları üretilmiştir (Şekil 9).

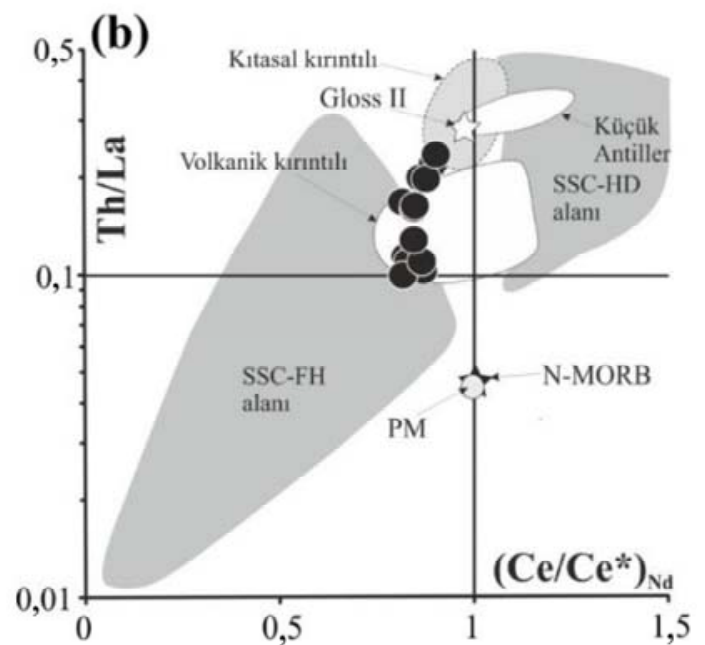

Şekil 9. (a) $\mathrm{Ba} / \mathrm{Rb}-\mathrm{Nb} / \mathrm{La}$ [41] ve $\left(\mathrm{Ce} / \mathrm{Ce}{ }^{*}\right)_{\mathrm{Nd}}$ ye karşı Th /La [42] ikili değişim diyagramları. SSC-HD: sulu sediment kil, SSC-FH: sediment, kil debris çökelleri

Şekil 9a'da verilmiş olan $\mathrm{Ba} / \mathrm{Rb}-\mathrm{Nb} / \mathrm{La}$ diyagramında düşük $\mathrm{Nb} / \mathrm{La}$ değerlerine karşın yüksek $\mathrm{Ba} / \mathrm{Rb}$ değerlerine doğru yönelen örnekler tipik olarak yitim bileşeninin varlığına işaret etmektedir. Diyagram üzerinde oldukça düşük $\mathrm{Ba} / \mathrm{Rb}$ değerleri akışkanlarla zenginleşmiş manto kaynak alanlarına işaret ederken, bunun aksine bu elementlerin oranlarının yüksek değerleri sediment ergimelerini yansitmaktadır [41]. Diyagramda yaklaşık 10'dan başlayıp yükselen değerlere doğru yönelen lav örnekleri tipik olarak sediment ergimelerinin varlığını yansıtmaktadır. Hasti ve arkadaşları [42] diyagramında ise (Şekil 9b) örnekler GLOSS bileşimi ile primitif ilksel kaynaklar arasına iz düşmekte ve tipik olarak yitim bileşeni ile zenginleşmiş manto kaynak alanlarının varlığını yansıtmaktadırlar. Tüm bu veriler volkanizmayı oluşturan manto kaynak alanının yitim bileşeni ile zenginleştiğine ve baskın olarak sediment ergimelerinin varlığına işaret etmektedir.

\subsection{Kısmi Ergime}

Lav örneklerinin kısmi ergime süreçlerini ortaya koyabilmek amacıyla NTE oranlarının kullanıldığı kısmi ergime modelleri üretilmiş ve bu lavların nasıl bir manto kaynak alanının ergimesi ile oluşabileceği ortaya koyulmaya çalışılmıştır. Nadir 
toprak elementler kısmi ergime süreçlerinde çok kullanışlıdırlar çünkü sipinel peridotitik veya granat peridotitik kaynağın kısmi ergimesinde nadir toprak elementler (REE) bu kaynak alanlara farklı katı-mineral/ergiyik paylaşım katsayısı ile katılırlar. Lavların kısmi ergime süreçlerini belirleyebilmek amaciyla Dy/Yb-La/Dy ve

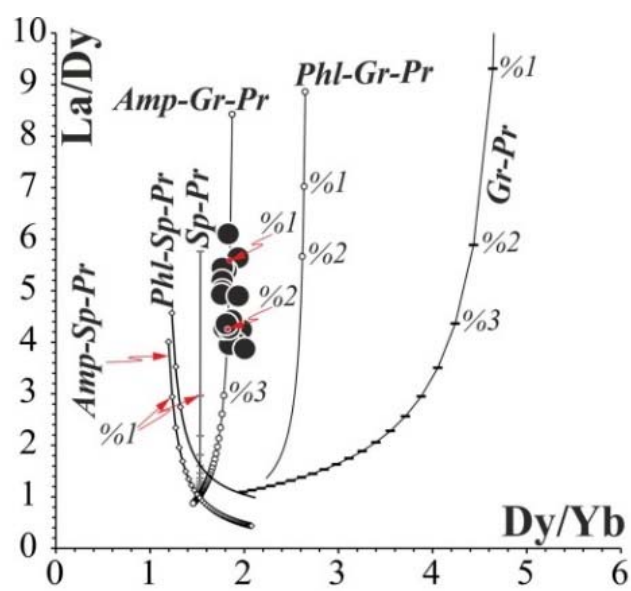

$\mathrm{La} / \mathrm{Yb}-\mathrm{Tb} / \mathrm{Yb}$ ikili değişim diyagramları üretilmiştir (Şekil 10). Bu diyagram üzerine farklı mineralojik bileşime sahip olabilecek manto kaynak alanlarına ait eğriler Shaw'ın [43] metodolojisi ve nonmodal (modal olmayan) yığın (batch) ergime eşitlikleri kullanılarak diyagram üzerine çizilmiştir.

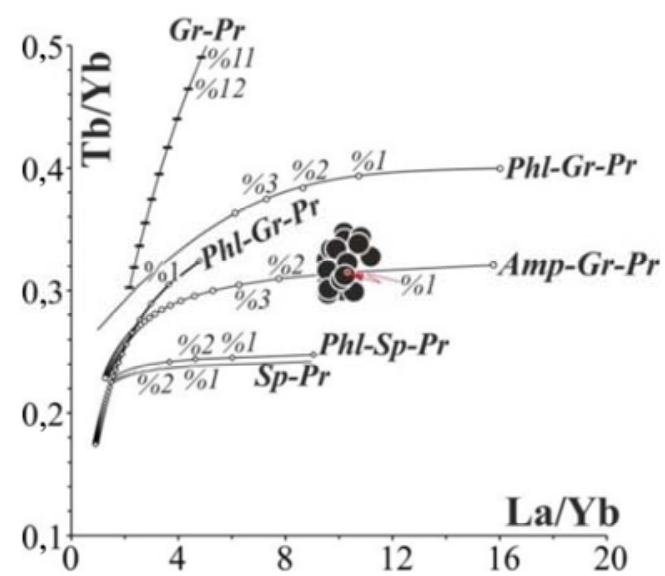

Şekil 10. Bazaltik lavların en az evrimleşmiş örneklerinin manto kaynak alanındaki ergime süreçlerini ortaya koyabilmek amaciyla üretilen $\mathrm{Dy} / \mathrm{Yb}-\mathrm{La} / \mathrm{Yb}$ ve $\mathrm{La} / \mathrm{Yb}-\mathrm{Tb} / \mathrm{Yb}$ ikili değişim diyagramları ile oluşturulan kısmi ergime modelleri. Modellerde kullanılan kaynak ve ergime mineral oranları Oyan ve arkadaşları [21]'dan alınmıştır. Kısmi ergime model eğrileri oluşturulurken kullanılan mineral/ergiyik ayrımlanma katsayıları $\left(K_{\mathrm{d}}\right)$ McKenzie ve O’Nions [44] ve Adam ve Green [45]'den alınmıştır

Tutak ve çevresindeki volkanik alanlarda mantoya ait herhangi bir ksenolit verisi elde edilemediğinden dolayı, primitif manto benzeri bir kaynağın iz element oranları kaynağın başlangıç bileşimi olarak alınmıștır. Zira Özdemir ve Güleç [20] ve Oyan ve arkadaşları [7,21]'nın çalışmaları Doğu Anadolu Bölgesi için en uygun kaynağın primitif manto benzeri bir kaynak olabileceğini petrolojik modellemeler ile ortaya koymuşlardır. Modellemelerde kullanılan eğriler oluşturulurken kullanılan kaynak ve ergiyik mineral oranları ile mineral/ergiyik ayrımlanma katsayısı değerleri Oyan ve arkadaşları [21]'dan alınmıştır.

Şekil 10 incelendiği zaman, bazaltik lavların, yaklaşık \%0,7 ile \%2 kısmi ergime dereceleri ile amfibolce zengin granat peridotit mineralojisine sahip bir manto kaynak alanının ergimesiyle elde edilebileceği görülmektedir. Amfibolün kaynak alandaki varlığ olan manto alanları ile uyumlu olduğu gibi, manto metasomatizma süreçleri ile sulu mineral fazlarının kalık mineral olarak mantoda oluştuğuna işaret etmektedir. Dalan okyanusal litosferin ergimesi ile meydana gelen ve yitim bileşeni ile metasomatize olmuş manto kaynak alanları amfibol ve/veya flogopit gibi sulu mineralleri kalık mineral fazı olarak içerebilmektedirler. En primitif lavların yüksek $\mathrm{Ba} / \mathrm{Rb} \quad(>16)$ ve düşük $\mathrm{Rb} / \mathrm{Sr} \quad(<0,03)$ oranları [46] flogopitten ziyade baskın olarak amfibolün sulu mineral olarak manto kaynak alanında kalık mineral fazını oluşturabileceğine işaret etmektedir.

\subsection{Jeodinamik}

Doğu Anadolu Bölgesi'ndeki tektonik rejim Geç Miyosen sonu ve Erken Pliyosen'e kadar sıkışma 
büzülme rejimi ile karakteristikken, bu tektonik rejim Erken-Geç Pliyosen'de sıkışma-açılma tektonik rejimine geçiş yapmıştır [16]. Doğu Anadolu Bölgesi için Arabistan-Avrasya plakalarının çarpışmasını takiben hüküm süren bu neotektonik yapı içerisinde, volkanik etkinlik geniş alanlarda yayılım göstermiş ve Miyosen'den Kuvaterner'e kadar büyük volkanik merkezlerden (Ağrı, Tendürek, Nemrut, Süphan v.b.) veya açılma çatlakları boyunca püskürmüştür. Doğu Anadolu Bölgesi'ndeki jeodinamik koşullar için birçok araştırmacı farklı modeller önermişlerdir $[1,3,9,17-19]$. Bu modellemeler içinde en çok kabul görenler; (1) litosferik mantonun alt bölümünün koparak (delaminasyon) astenosfer içine batması [1,2,7], (2) dalan okyanusal litosferin (slabın) dikleşmesi ve kırılması (slab steeping and break off) $[3,9,10,19]$ şeklinde özetlenebilir. Özdemir ve Güleç [20] ve Oyan ve arkadaşları [7] son yaptıkları çalışmalarda, bölge çapında gözlenen yoğun magmatik etkinliğin granat ve spinelce zengin kaynak mineralojilerine sahip olan ve belirgin yitim bileşeni içeren manto kaynak alanlarının farklı ergime derecelerinde ve değişken oranlarda ergiyerek karışması ile oluşabileceğini ve spinelce zengin manto kaynak alanındaki kısmi ergimelerin katkısının Miyosen'den Kuvaterner'e doğru arttığını belirtmişlerdir.

2003 yılında yapılmış olan jeofizik çalışmalar (MT), Doğu Anadolu Bölgesi'nin altında litosferik mantonun olmadığı ve kabuğun direk astenosferik mantonun üzerinde bulunduğu şeklinde yorumlanmıştır [47-51]. Bunun yanı sıra jeofizik verilerin değerlendirildiği bazı çalışmalar ise, bölge altındaki yaklaşık 70-90 km civarında litosferin varlığına [51] işaret etmektedir. $\mathrm{Bu}$ veriler 1şı̆̆ında, Doğu Anadolu Bölgesi'nin litosferik kabuğunun yaklaşık $45 \mathrm{~km}$ civarında olduğu düşünüldüğü zaman [48,49], bölge altında yaklaşık 25 ile $45 \mathrm{~km}$ arasındaki kalınlıklarda bir litosferik mantonun varlığı ortaya çıkmaktadır. Bu veriler ve Tutak volkanitlerinin manto kaynak alanında amfibolün varlığı, bu alandaki bazaltik volkanizmanın bölgedeki litosferik kopma ve kopan litosferik mantonun astenosfer içine batmasını takiben astenosferik mantonun yükselimi ve yitim bileşeni bakımından zenginleşmiş olan litosferik mantonun tabanının ergimesiyle oluşabileceğine işaret eder. Deneysel çalışmalar [52] ve litosferik manto ksenolitleri içinde bulunan amfiboller [53] üzerindeki çalışmalar 1030 ile $1200{ }^{\circ} \mathrm{C}$ sicaklıkta ve 2,5-3 Gpa basınç altında amfibol minerallerinin stabil olabileceğine işaret etmektedir. Bu veriler yaklaşık $80-90$ km (1 Gpa yaklaşık $30 \mathrm{~km}$; Oyan ve arkadaşları [21]) derinlikte, litosfer-astenosfer sınırında, kıta altı metasomatise olmuş litosferik mantonun ergimeleri ile Tutak volkanitlerinin oluşabileceğine işaret etmektedir.

\section{SONUÇLAR}

Tutak çevresindeki gözlenen Pliyosen yaşlı [23] mafik volkanizmanın petrolojisi üzerine gerçekleştirilen bu çalışma, mafik lavların bazaltik bileşimde olduklarını ve alkali-subalkali ayrım çizgisi üzerinde sodik karakterisitkler sunduklarını göstermiştir. Tutak volkanitlerine ait lavların jeokimyasal ve izotopik analiz sonuçları ile üretilen EC-AFC petrolojik modellemeleri, bu bazaltik lavların fraksiyonel kristallenmeden ziyade kıtasal kirlenmeye maruz kaldıklarına ve baskın olarak kitasal kirlenmeyle kabuksal seviyelerde evrimleştiklerine işaret etmektedir. Uyumsuz element örümcek diyagramlarında, $\mathrm{MgO}$ değerleri yüksek ve petrolojik modellemeler sonucunda kitasal kirlenme süreçlerinden etkilenmediği belirlenen bazaltik örneklerde gözlenen $\mathrm{Nb}$ ve Ta elementlerindeki tüketilme tipik olarak yitim bileşenini varlığına işaret ederken, $\mathrm{MgO}$ değerleri düşük olan örnekler için AFC süreçlerinin izlerini yansıtmaktadır. Üretilen kısmi ergime modelleri, bu bazaltik lavların yaklaşık \%0,7 ile $\% 2$ arasındaki kısmi ergime derecelerinde amfibolce zengin granat peridotit kaynağının ergimesiyle üretilebileceğine işaret etmiştir. Amfibolün manto kaynak alanındaki varlığı ve Doğu Anadolu Bölgesi'nin ortaya koyulmuş litosferik yapısı göz önüne alındığ1 zaman, Tutak volkanitlerine ait lavların litosferastenosfer sınırında, metasomatize olmuş litosferik mantonun temelindeki kismi ergimeler ile üretilebileceği ortaya koyulmuştur. 


\section{TEŞEKKÜR}

Bu çalışma, Van Yüzüncü Yıl Üniversitesi Bilimsel Araştırma Projeleri Koordinasyon birimi tarafından desteklenmiştir (Proje No: 2015-MíMB113).

\section{KAYNAKLAR}

1. Pearce, J.A., Bender, J.F., De long, S.E., Kidd, W.S.F., Low, P.J., Güner, Y., Şaroğlu, F., Y1lmaz, Y., Moorbath, S., Mitchell, G.J., 1990. Genesis of Collision Volcanism in Eastern Anatolia, Turkey. Journal of Volcanology and Geothermal Research, 44,189-229.

2. Keskin, M., Pearce, J.A., Mitchell, J.G., 1998. Volcano-stratigraphy and Geochemistry of Collision-related Volcanism on the ErzurumKars Plateau, North Eastern Turkey, Joural of Volcanology and Geothermal Research, 85, 355-404.

3. Keskin, M., 2003. Magma Generation by Slab Steepening and Breakoff Beneath a Subduction-accretion Complex: An Alternative Model for Collision-related Volcanism in Eastern Anatolia, Turkey. Geophysical Research Letter, 30, 8046-8050.

4. Allen, M.B., Kheirkhah, M., Neill, I., Emami, M.H., McLeod, C.L., 2013. Generation of Arc and Within-plate Chemical Signatures in Collision Zone Magmatism: Quaternary Lavas from Kurdistan Province, Iran. Journal of Petrology, 54, 887-911.

5. Neill, I., Meliksetian, Kh., Allen, M.B., Navarsardyan, G., Karapetyan, S., 2013. Pliocene-Quaternary Volcanic Rocks of NW Armenia: Magmatism and Lithospheric Dynamics Within an Active Orogenic Plateau. Lithos, 180-181, 200-215.

6. Neill, I., Meliksetian, Kh., Allen, M.B., Navarsardyan, G., Kuiper, K., 2015. Petrogenesis of Mafic Collision Zone Magmatism: The Armenian Sector of the Turkish-Iranian Plateau. Chemical Geology, 403, 24-41.

7. Oyan, V., Keskin, M., Lebedev, V.A., Chugaev, A.V., Sharkov, E.V., 2016. Magmatic Evolution of the Early Pliocene
Etrüsk Stratovolcano, Eastern Anatolia Collision Zone, Turkey. Lithos, 256-257, 88-108.

8. Lebedev, V.A., Sharkov, E.V., Ünal, E., Keskin, M., 2016. Late Pleistocene Tendürek Volcano (Eastern Anatolia, Turkey): II. Geochemistry and Petrogenesis of the Rocks. Petrology, 24, 234-270.

9. Şengör, A.M.C., Özeren, S., Zor, E., Genç, T., 2003. East Anatolian High Plateau as a Mantlesupported, N-S Shortened Domal Structure. Geophysical Research Letter, 30, 8043-8045

10. Şengör, A.M.C., Özeren, S., Keskin, M., Sakınç, M., Özbakır, A.D., ve Kayan, I., 2008. Eastern Turkish High-plateau as a Small Turkish Type Orogen: Implications for Postcollisional Crust-forming Processes in Turkic Type Orogens, Earth sciences Rewievs, 90, 1-48.

11. Yılmaz, Y., Şaroğlu, F., Güner, Y., 1987. Initation of the Neomagmatism in East Anatolia. Tectonophysics, 137,177-199.

12. Okay, A.I., Zatin, M., Cavazza, V., 2010. Apatite Fission-track Data for the Miocene Arabia-Eurasia Collision. Geology, 38, 35-38.

13. Karaoğlan, F., Parlak, O., Thöni, M., Klötzli, U., Koller, F., 2016. The Temporal Evolution of the Active Margin Along the Southeast Anatolian Orogenic Belt (SE Turkey): Evidence from U-Pb, Ar-Ar and Fission Track Chronology. Gondwana Research, 33, 190-208.

14. Oyan, V., 2018. Ar-Ar Dating and Petrogenesis of the Early Miocene Taşkapı-Mecitli (ErcişVan) Granitoid, Eastern Anatolia Collisional Zone, Turkey. Journal of Asian Earth Sciences, 158, 210-226.

15. Lebedev, V, A., Sharkov, E.V., Keskin, M., Oyan, V., 2010. Geochronology of Late Cenezoic Volcanism in the Area of Lake Van, Turkey: An Example of Developmental Dynamics for Magmatic Processes. Doklady Earth Science, 433, 1031-1037.

16. Koçyiğit, A., Yılmaz, A., Adamia, S., Kuloshvili, S., 2001. Neotectonics of East Anatolian Plateau (Turkey) and Lesser Caucasus: Implication for Transition from Thrusting to Strike-slip Faulting. Geodinamica Acta, 14, 177-195. 
17. Innocenti, F., Mazzuoli, R., Pasquaré, G., Radicati di Brozolo, F., Villari, L., 1982. Tertiary and Quaternary Volcanism of the Erzurum-Kars area (Eastern Turkey): Geochronological data and Geodynamic Evolution. Joural of Volcanology and Geothermal Research, 13, 223-240.

18. Yılmaz, Y., Güner, Y., Şaroğlu, F., 1998. Geology of the Quaternary Volcanic Centres of the East Anatolia. Journal of Volcanology and Geothermal Research, 137, 177-199.

19. Keskin, M., 2007. Eastern Anatolia: A Hot Spot in a Collision Zone Without a Mantle Plume. GSA Special Paper, 430, 695-722.

20. Özdemir, Y., Güleç, N., 2014. Geological and Geochemical Evoluation of Quaternary Süphan Stratovolcano, Eastern Anatolia, Turkey: Evidence for the Lithosphere-asthenosphere Interaction in Post Collisional Volcanism, Journal of Petrology, 55, 37-62.

21. Oyan, V., Keskin, M., Lebedev, V.A., Chugaev, A.V., Sharkov, E.V., Ünal, E., 2017. Petrology and Geochemistry of the Quaternary Mafic Volcanism in the Northeast of Lake Van, Eastern Anatolian Collision Zone, Turkey. Journal of Petrology, 58, 1701-1728.

22. Köksal, S., Göncüoğlu, M.C., 2008. Sr and Nd Isotopic Characteristics of Some S-I and Atype Granitoids from Central Anatolia. Turkish Journal of Earth Sciences, 17, 111-127.

23. Oyan, V., Özdemir, Y., Jourdan, F., 2015. Petrologic Evolution of Karayazı Basaltic Plateau: Mixture of Melts-derived from Both Spinel and Garnet lherzolite. EGU 2016, 18, 1005, Viyana, Avusturya.

24. Yılmaz, A., Terlemez, İ., Uysal, Ş., 1986. Erzurum'un Güneydoğusunda Yer Alan Hınıs, Tekman ve Karayazı Arasının Jeolojisi ve Volkanik Kayaçların Petrolojisi. Maden Tetkik ve Arama Genel Müdürlüğü Derleme Raporu. Rapor No: 8089, 37.

25. Soytürk, N., 1973. Murat Baseni Jeolojisi ve Hidrokarbon İmkanları Raporu. TPAO Arama Grup Başkanlığı Jeoloji Müdürlüğü Raporu. Rapor No: 791, 22.

26. Oyan, V., 2011. Etrüsk Volkanı ve Çevresinin (Van Gölü Kuzeyi) Volkano Stratigrafisi, Petrolojisi ve Magmatik Evrimi (Doktora tezi, basılmamış). Van YYÜ, Fen Bilimleri Enstitüsü, Van.

27. Le Bas, M.J., Le Maitre, R.W., Streckeisen, A., Zanettin, B., 1986. A Chemical Classification of Volcanic Rocks Based on the Total Alkalisilica Diagram. Journal of Petrology, 27, 745-750.

28. Middlemost, E.A.K., 1975. The Basalt Clan. Earth Science Reviews, 11, 337-364.

29. Peccerillo, A., Taylor, S.R., 1976. Geochemistry of Eocene Calc-alkaline Volcanic Rocks from the Kastamonu Area. Northern Turkey. Contributions to Mineralogy and Petrology, 58, 63-81.

30. Irvine, N., Baragar, W.R.A., 1971. A Guide to Chemical Classification of the Common Volcanic Rocks. Canadian Journal of Earth Science, 8, 523-548.

31. Kuno, H., 1968. Lateral Variation of Basalt Magma Types Across Continental Margins and Island Arcs. Bulletin of Volcanology, 29, 195-222.

32. Sun, S.S., McDonough, W.F., 1989. Chemical and Isotopic Systematics of Oceanic Basalts: Implications for Mantle Composition and Processes. (Magmatism in Ocean Basins, editor Saunders, A.D., Norry, M.J.) Magmatism in Ocean Basins. Geological Society of London Special Publication, 42, 313-345.

33. Keskin, M., Pearce, J.A., Kempton, P.D., Greenwood, P., 2006. Magma-crust Interactions and Mama Plumbing in a Postcollisional Setting: Geochemical Evidence from the Erzurum-Kars Volcanic Plateau, Eastern Turkey. Geological Society of America Special Paper, 409, 475-505.

34. Bohrson, W. A., Spera, F. J., 2001. Energyconstrained Open-system Magmatic Processes II: Application of Energy-constrained Assimilation-fractional Crystallization (ECAFC) Model to Magmatic Systems. Journal of Petrology, 42, 1019-1041.

35. Spera, F.J., Bohrson, W.A., 2001. Energyconstrained Open-system Magmatic Processes I: General Model and Energy-constrained Assimilation and Fractional Crystallization (EC-AFC) Formulation. Journal of Petrology, 42, 999-1018. 
36. Taylor, S.R., McLennan, S.M., 1985. The Continental Crust: its Composition and Evolution, Geoscience Texts. Blackwell Scientific Publications, London.

37. Hofmann, A.W., 1997. Mantle Geochemistry: the Message from Oceanic Volcanism. Nature, $385,219-229$.

38. Hawkesworth, C.J., Gallagher, K., Hergt, J. M., McDermott, F., 1993. Mantle and Slab Contributions in Arc Magmas. Annual Review of Earth and Planetary Sciences, 21, 175-204.

39. Hawkesworth, C.J., Turner, S.P., McDermott, F., Peate, D.W., Van Calsteren, P., 1997. U-Th Isotopes in Arc Magmas: Implications for Element Transfer from the Subducted Crust. Science, 276, 551-555.

40. Turner, S., Bourdon, B., Gill, J., 2003. Insight into Magma Genesis at Convergent Margins from U-series Isotopes. In: Bourdon, B., Henderson, G.M., Lundstrom, C.C., Turner, S.P. (eds) Uranium-Series Geochemistry. Reviews in Mineralogy and Geochemistry, Mineralogical Society of America, 52, 255-310.

41. Wang, K.L., Chung, S., O’Reilly, S.Y., Sun, S., Shinjo, R., Chen, C., 2004. Geochemical Constraints for the Genesis of Post-collisional Magmatism and the Geodynamic Evolution of the Northern Taiwan Region. Journal of Petrology, 45, 975-1011.

42. Hasti, A.R., Mitchell, S.F., Treloar, P.J., Kerr, A.C., Neill, I., Barfod, D.N., 2013. Geochemical Components in a Cretaceous Island arc: The $\mathrm{Th} / \mathrm{La}-(\mathrm{Ce} / \mathrm{Ce} *) \mathrm{Nd}$ Diagram and Implications for Subduction Initiation in the Inter-American Region. Lithos, 162-163, 57-69.

43. Shaw, D.M., 1970. Trace Element Fractionation During Anatexis. Geochimica et Cosmochimica Acta, 34, 237-243.

44. Mc Kenzie, D.P., O’Nions, R.K., 1991. Partial Melt Distributions from Inversion of Rare Earth Element Concentrations. Journal of Petrology, 32, 1021-1091.

45. Adam, J., Green, T., 2006. Trace Element Partitioning Between Mica-and AmphiboleBearing Garnet lherzolite and Hydrous Basanitic Melt: 1. Experimental Results and the Investigation of Controls on Partitioning
Behavior. Contributions to Mineralogy and Petrology, 152, 1-17.

46. Furman, T., Graham, D., 1999. Erosion of Lithospheric Mantle Beneath the East African Rift System: Geochemical Evidence from the Kivu Volcanic Province. Lithos, 48, 237-262.

47. Al-Lazki, A., Seber, D., Sandvol, E., Türkelli, N., Mohamad, R., Barazangi, M., 2003. Tomographic Pn Velocity and Anisotropy Structure Beneath the Anatolian Plateau (eastern Turkey) and the Surrounding Regions. Geophysica Research Letter, 30, 8043-8046.

48. Gök, R., Türkelli, N., Sandvol, E., Seber, D., Barazangi, M., 2000. Regional Wave Propogation in Turkey and Surrounding Regions, Geophysical Research Letter, 27, 429-432.

49. Gök, R., Sandvol, E., Türkelli, N., Seber, D., Barazangi, M., 2003. Sn Attenuation in the Anatolian and Iranian Plateau and Surrounding Regions. Geophysical Research Letter, 30, $8038-8042$.

50. Sandvol, E., Türkeli, N., Barazangi, M., 2003. The Eastern Turkey Seismic Experiment: The Study of a Young Continent-continent Collision. Geophysical Research Letter, 30, 8035-8038.

51. Angus, D.A., Wilson, D.C., Sandvol, E., Ni, J.F., 2006. Lithospheric Structure of the Arabian and Eurasian Collision Zone in Eastern Turkey from S-wave Receiver Functions. Geophysical Journal of International, 166, 1335-1346.

52. Wallace, M.E., Green, D. H., 1991. The Effect of Bulk Rock Composition on the Stability of Amphibole in the Upper Mantle: Implications for Solidus Positions and Mantle Metasomatism. Mineralogy and Petrology 44, 1-19.

53. Witt-Eickschen, G., Seck, H.A., Mezger, K., Eggins, S.M., Altherr, R., 2003. Lithospheric Mantle Evolution Beneath the Eifel (Germany. Journal of Petrology, 44, 1077-1095. 